\title{
Factors affecting the occurrence of early maturing males in the protandrous pandalid shrimp Pandalus latirostris
}

\author{
Susumu Chiba ${ }^{1, *}$, Seiji Goshima ${ }^{1}$, Toshihiro Mizushima ${ }^{2}$ \\ ${ }^{1}$ Department of Marine Biological Science, Faculty of Fisheries, Hokkaido University, Hakodate 041-8611, Japan \\ ${ }^{2}$ Hokkaido Central Fisheries Experimental Station, Yoichi 046-8555, Japan
}

\begin{abstract}
Some Age-0 males of the protandrous pandalid shrimp Pandalus latirostris Rathbun mature in their first year, and the proportion of these early maturing males (EMMs) in a population varies both locally and annually. Two laboratory experiments and 2 field observations were conducted to clarify the factors affecting the occurrence of EMMs. The first experiment showed that EMMs needed to grow fast until the breeding season and began producing sperm at about $14 \mathrm{~mm}$ carapace length. Individuals with an AMP (length of the endopod/length of the appendix masculina) value above 40 were defined as EMMs. In the second experiment, the effects of food amount, hatching date and maternal size on growth at Age-0 were examined. Food amount strongly affected the early growth. A difference in hatching date of $>2$ wk caused a large difference in body size of juveniles; this difference was maintained until the breeding season 3 mo later. Large females spawned larger larvae than small females, but the size difference between larvae from large females and those from small females decreased with time. Field observations showed that at one site in Saroma Lagoon, Hokkaido, Japan, hatching occurred over a 1 mo period. In 1996/1997, we found no obvious differences of size distribution of Age-0 individuals and the occurrence of EMM as a function of location in the lagoon or year. These results may have been caused by slow growth, because water temperatures in the lagoon were much colder in 1996/1997 than during 1987 to 1995 . We conclude that the occurrence of EMMs is closely related to various environmental factors in shallow waters. Therefore, the proportion of EMMs may fluctuate both locally and annually. This study shows that a small difference in juvenile growth over a short period can alter the subsequent life history of $P$. latirostris.
\end{abstract}

KEY WORDS: Protandry $\cdot$ Pandalid shrimp $\cdot$ Growth $\cdot$ Maturity $\cdot$ Life history variation

\section{INTRODUCTION}

A trade-off often exists between growth and reproduction in various animals. As a result, age and/or size at first reproduction can vary both within a species and among species to maximize fitness (Partridge \& Harvey 1985, Roff 1992). In sequential hermaphroditic species, their reproductive success is closely related with their age/size when they change their sex (Ghiselin 1969, Warner 1975, Charnov 1982). If the timing of

*E-mail: schiba@fish.hokudai.ac.jp sex-change is determined by the growth of individuals determining the age/size at the start of maturity in the sexual stage before the change may be an important factor in understanding their life history, because this maturity affects the sequential growth and maturity after the change. However, few studies have examined the process of maturation during the sexual stage for sequential hermaphrodites before the sex-change.

Pandalid shrimps are protandric (male first) hermaphrodites. The age/size at which the sex-change occurs varies among latitudes and by year, even in the same species (Rasmassen 1953, Butler 1964, Haynes \& Wigley 1969, Charnov 1979, Bergström 1992). Almost 
all populations have early maturing females (EMFs) that mature younger (smaller) than normal females (Charnov 1979). Two routes exist for becoming an EMF: (1) directly becoming a female without a sexchange (primary female, $\mathrm{PF}_{\text {; }}$ Bergström 1997), or (2) becoming a female after $1 \mathrm{yr}$ as an early maturing male (EMM). There has been little study on variations of the age at male maturation in pandalid shrimps.

Pandalus latirostris Rathbun ( $P$. kessleri Czerniavsky is a synonym of this species; Holthuis 1995) is distributed mainly in northern Japan and eastern Russia, where it is a commercially important species (Kubo 1951, Sitonikov et al. 1997). This species spends its whole life in seagrass beds at water depths $\leq 4 \mathrm{~m}$, where it undergoes direct development. In northern Japan, this species generally hatches in spring, and matures in autumn at Age-1, mating as female at $\geq$ Age-2. EMMs (Age-0) or EMFs (Age-1) also form a small proportion of the population (Aoto 1952, Mizushima 1981a, 1984, Mizushima \& Omi 1982). The occurrence of EMMs fluctuates both annually and at small scales (e.g., within the same bay) (Mizushima 1981a, 1984).

Questions about EMMs remain. First, do EMMs truly exist? Because Pandalus latirostris does not have an obvious age marker, it is aged by separating each cohort by means of the length-frequency distribution of populations in past studies. Therefore, extremely small, slow-growing Age-1 males may have mistakenly been identified as EMMs in earlier studies. Second, the degree of maturation has been judged only by an index of the appendix masculina percentage (AMP; see 'Materials and methods' for details) (Aoto 1952, Mizushima \& Omi 1982), without histological investigation of the gonads, so it remains unclear if EMMs can produce sperm. It has been assumed that body size influences occurrence of EMMs since EMMs are larger than almost all other Age-0 individuals (Mizushima 1981a). Few studies have examined growth in the early stages. Even if effective growth factors in the early stages show small differences, large differences may occur during the life history of P. latirostris.

The present study is based on 2 laboratory experiments and 2 field observations aimed at clarifying the factors leading to the occurrence of EMMs. The first experiment was carried out to ascertain the existence of EMMs and to evaluate the relationship between maturation and body size, and between maturation and AMP index. In the second experiment, we examined the effects of growth factors that have been suggested to be potential factors in past field observations on Pandalus latirostris (Mizushima \& Omi 1982), such as amount of food and hatching date. The size of the eggs a female carries increases with increasing female body size (Mizushima unpubl. data). Because maternal size often affects offspring size and larger offspring often show fast growth (e.g., Roff 1992), the growth of juveniles may be determined by maternal size. Therefore, we examined maternal size as a third potential factor. Field observations were made during both hatching and breeding seasons in Saroma Lagoon, eastern Hokkaido, Japan (Fig. 1), to clarify the duration of the hatching period at 1 location, and to compare the size distribution of the Age- 0 class and the occurrence of EMMs as a function of location in the lagoon and of year.

\section{MATERIALS AND METHODS}

Growth experiment. Expt 1: In late May 1996, many ovigerous female Pandulas latirostris Rathbun were

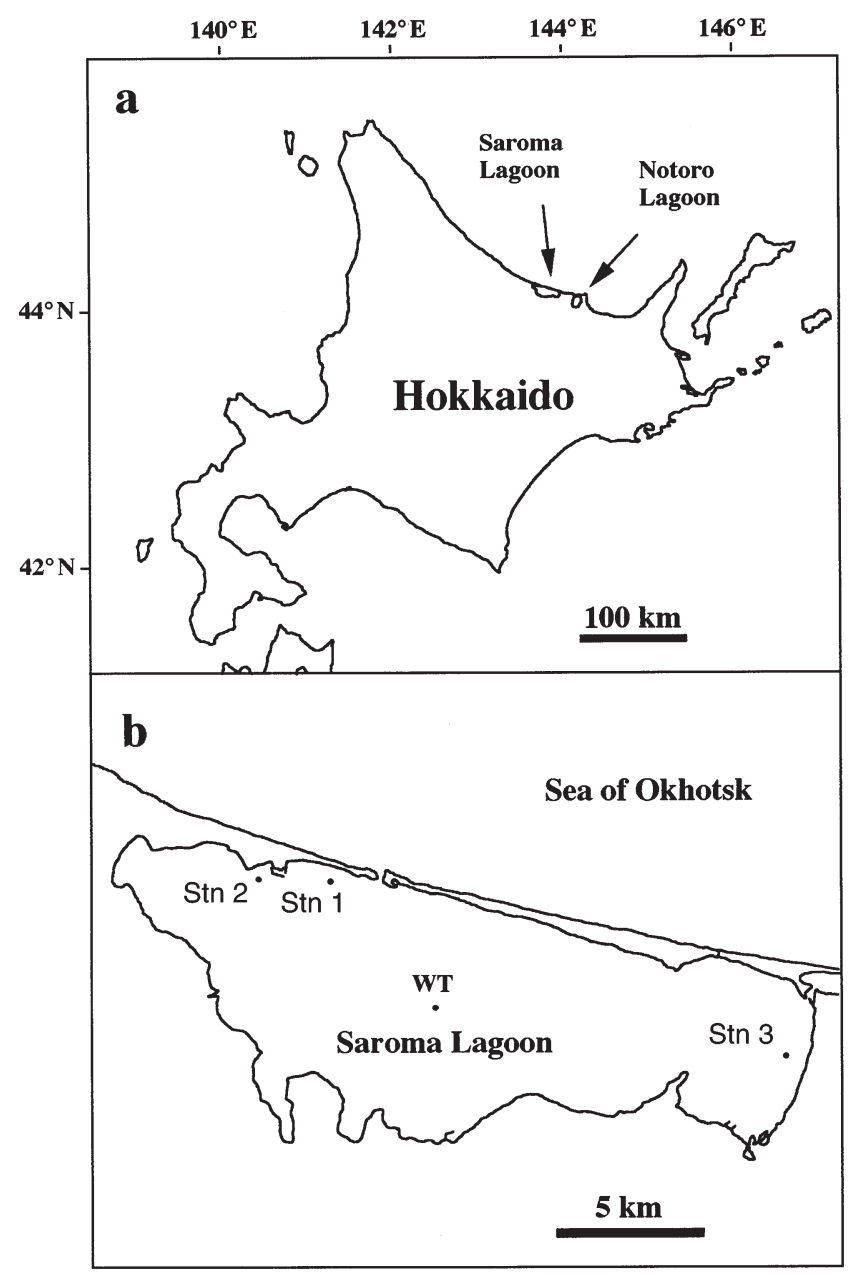

Fig. 1. (a) Map of Saroma and Notoro Lagoon on the northeast Hokkaido coast; (b) sampling stations (Stns 1, 2 and 3) and the station where water temperatures were measured in Saroma Lagoon (WT) 
collected in Saroma Lagoon (Stn 3; Fig. 1) and maintained at the Abashiri Marine Science Center on the coast of Notoro Lagoon (Fig. 1a). The eggs of 8 females hatched at the same time. It took $3 \mathrm{~d}$, from 3 to 5 June 1996, to completely hatch all the eggs.

Because the larvae have difficulty surviving until about the fifth stage (i.e., ca 4 wk old), preliminary rearing was performed before the main experiment. Larvae were kept in aerated 21 aquaria under constant environmental conditions from hatching day to 21 July; 20 larvae from each brood were then distributed to either 2 or 3 aquaria, making a total of 20 aquaria for all larvae collected. A nylon net (1 mm mesh) was placed in each aquarium as a refuge. Water temperature was maintained at $\sim 18^{\circ} \mathrm{C}$. The larvae were fed Artemia sp. nauplii daily until the larvae were $\sim 2 \mathrm{wk}$ old, after which they were fed frozen mysid Neomysis intermedia.

Expt 1 was carried out from 22 July to 22 September, the late breeding season. To determine if body size affected the occurrence of EMMs, we used 2 experimental aquaria (blocks) with different amounts of food; larvae in the fast-growth block were fed an overabundant amount of frozen mysids and commercial compound, and those in the slow-growth block received half the amount given to the fast-growth block. Each aquarium was divided equally into 64 compartments $(10 \times 10 \times 15 \mathrm{~cm}$ high) using a plastic net (Tricalnet, $3 \mathrm{~mm}$ mesh, Takiron Corp.). In each aquarium, 64 individuals ( 8 from each of 8 different females) were placed individually in each compartment. The aquaria were exposed to a natural photoperiod. The water was maintained at the same temperature as that in the lagoon by sinking the aquaria in a bath with water pumped from the Notoro Lagoon. After the experiment, all juveniles were fixed in $10 \%$ seawater formalin and their carapace lengths (CLs) were measured. The degree of maturity was estimated using the AMP index (Aoto 1952):

$$
\text { AMP index }=A M / E N \times 100
$$

where $A M=$ the length of the appendix masculina, and $E N=$ the length of the endopod on the second pleopod (Fig. 2).

The gonads of each juvenile were embedded in paraffin, cut into $7 \mu \mathrm{m}$ sections, and stained with Derafield's hematoxylin and eosin. Testis development was divided into 4 stages: immature, spermatocyte, spermatoblast, and sperm. Individuals with a testis in the sperm stage were classified as an EMM.

Expt 2: In early May 1997, many ovigerous females were collected at Stn 3 in Saroma Lagoon and transferred to the laboratory, where they were reared in aquaria at $5^{\circ} \mathrm{C}$.

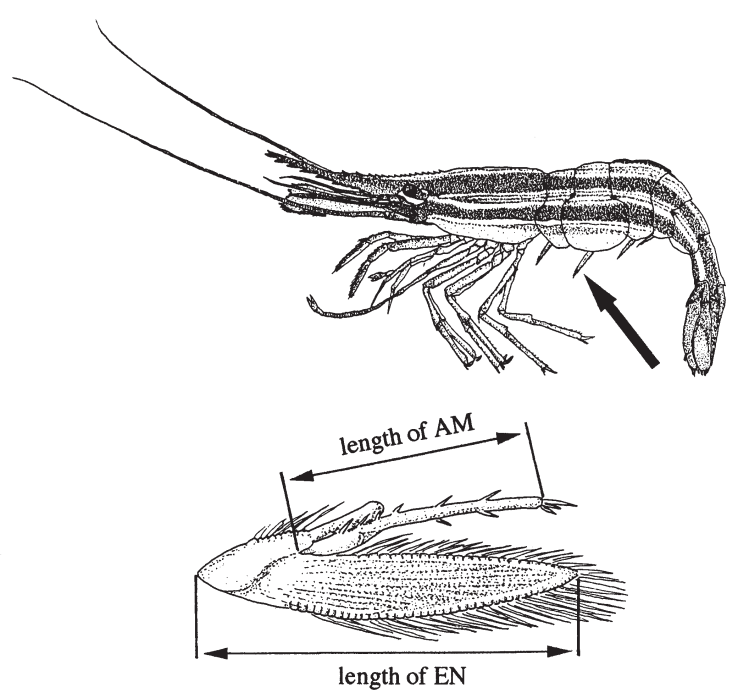

Fig. 2. Pandalus latirostris. Position of 2nd pleopods (upper arrow), and parts of endopod (EN) and appendix masculina (AM) that were measured

Larvae were induced to hatch by increasing the rearing water temperature to $\sim 18^{\circ} \mathrm{C}$ from 25 to 29 May (early hatch: $\mathrm{EH}$ ), and were classified into 2 maternal size-groups: large (LM, $\mathrm{n}=6, x=31.27 \pm 2.00 \mathrm{~mm}$ [SD]) and small (SM, $\mathrm{n}=6, x=25.70 \pm 0.90 \mathrm{~mm}$ [SD]). Maternal size between the groups was statistically different (1-way ANOVA, $F=38.86, \mathrm{p}<0.0001$ ). Moreover, each maternal group was divided into 2 feeding groups: an abundant food (AF) and a poor food (PF) group, the latter receiving half the amount of food received by the former. The hatching dates in both maternal size-groups were not significantly different (1-way ANOVA, $F=0.22, p=0.65$ ), so both groups were regarded as hatching at the same time. Larvae that hatched from 7 to 13 June (late-hatch, LH) were also classified into 2 maternal size-groups: LM ( $\mathrm{n}=6, \mathrm{x}=$ $31.87 \pm 1.84 \mathrm{~mm}[\mathrm{SD}])$ and $\mathrm{SM}(\mathrm{n}=6, x=24.92 \pm 1.61$ $\mathrm{mm}$ [SD]). Maternal size between the groups was statistically different (1-way ANOVA, $F=48.57, \mathrm{p}<$ 0.0001). Each maternal size-group was divided into 2 feeding groups as for the EH group. The hatch dates in both maternal size-groups of the LH group were not statistically significant (1-way ANOVA, $F=1.00, \mathrm{p}=$ 0.34). Maternal sizes of the LM group between the EH and the LH groups were statistically similar (1-way ANOVA, $F=1.07, \mathrm{p}=0.33$ ), as were the maternal sizes of the SM group between both hatch groups (1-way ANOVA, $F=0.30, p=0.60$ ). Larvae were divided among 8 treatments: EH-LM-AF, EH-SM-AF, EH-LMPF, EH-SM-PF, LH-LM-AF, LH-SM-AF, LH-LM-PF, LH-SM-PF. We randomly selected 40 larvae for each treatment. One aquarium with recirculating water 
made up an experimental block and each block had 4 replicates. We exchanged half the water in each aquarium daily. The aquaria were randomly placed on a steel shelf, and nets were put into each aquarium as a shelter. They were exposed to a natural photoperiod, and the water temperature was maintained at $\sim 18^{\circ} \mathrm{C}$. Individuals were fed Artemia sp. nauplii for $\sim 2 \mathrm{wk}$ after hatching, and then frozen mysids and a commercial compound. This experiment was continued until the middle of the breeding season (10 September 1997).

The CLs of 6 to 10 randomly chosen newly hatched larvae from the same brood were measured. We photographed all individuals on 7 July, 3 August, and 10 September, and measured the CL of the juveniles from the photos. To analyze the effect of each growth factor since hatching, we used a nested analysis of variance (ANOVA), since 3 growth factors were nested within a block.

Field observations. Changes in water temperature in Saroma Lagoon: To analyze the changes in water temperature in Saroma Lagoon from May to October, the growth period of Pandalus latirostris, we used data recorded at $3 \mathrm{~m}$ water depth (WT; Fig. 1b) (Saroma-ko Fisheries Cooperative Association of Aquaculture 1997).

Hatching season: Larvae were collected from Saroma Lagoon approximately every $5 \mathrm{~d}$ from 1 May to 4 July 1997 (no data on 15 June). All samplings were carried out in the seagrass (Zostera marina and Z. caespitosa) area, Stn 3 (Fig. 1, bottom depth about $1.5 \mathrm{~m}$ ). Each sample consisted of 10 pooled catches from $10 \mathrm{~m}$ long hauls with a Norpac net (mouth opening $45 \mathrm{~cm}$, length $180 \mathrm{~cm}, 334 \mu \mathrm{m}$ mesh). All samples were fixed in $10 \%$ seawater formalin, and the stages of the larvae were identified using the descriptions of Kurata (1955). As Pandalus latirostris larvae first molt approximately $4.5 \mathrm{~d}$ after hatching (Kurata 1955, Omi \& Mizushima 1972), we assumed that the first-stage individuals collected at each sampling were newly hatched.

Breeding season: This investigation was conducted in late September 1996 and 1997 in Saroma Lagoon. Three sampling stations were chosen with a bottom depth of about $1.5 \mathrm{~m}$, having nearly the same density of seagrass. A trawl net with a sledge (mouth opening $1.5 \times 0.5 \mathrm{~m}$, length $1.8 \mathrm{~m}, 3 \mathrm{~mm}$ mesh) was trawled for $50 \mathrm{~m}$ hauls at each station at a constant speed of $\sim 0.28 \mathrm{~m} \mathrm{~s}^{-1}$. All samples were fixed in $10 \%$ seawater formalin. Subsequently, the CLs were measured using calipers to the nearest $0.1 \mathrm{~mm}$. Length-frequency distributions were constructed for $1 \mathrm{~mm}$ size-classes. Cohorts assumed to be year classes in the lengthfrequency distributions were separated using the computer program PROGEAN (Tsutsumi 1990). Sexes were identified based on the form of the first and sec- ond pleopods, following the descriptions of Kubo (1951) and Kashiwagi (1974). The degree of maturity in males was determined by the AMP index. Individuals of the Age-0 group with AMP $\geq 50$ were defined as EMMs. Moreover, we confirmed whether the EMMs were functionally male by visual examination of the form of the vas deferens: vas deferentias in Pandulas latirostris are coiled when the shrimps mature as males (Kubo 1951). A small number of samples could not be examined because of inadequate fixation.

ANOVA was used to compare the CL-frequency distributions among sampling stations and between years. Fisher's protected least significant difference (PLSD) was used as a post-hoc test. G-tests were used to compare the percentage of occurrence of EMMs among stations and between years.

\section{RESULTS}

\section{Growth experiment}

Expt 1

The number of surviving Pandulas latirostris (52 individuals $=81.3 \%$ ) in both growth blocks was equal. Fig. 3 shows the relationship between CL and AMP of individuals in abundant and poor food conditions. The value of AMP increased significantly with increasing CL $\left(\mathrm{n}=99, \mathrm{r}^{2}=0.777, \mathrm{p}<0.0001\right)$. Individuals with

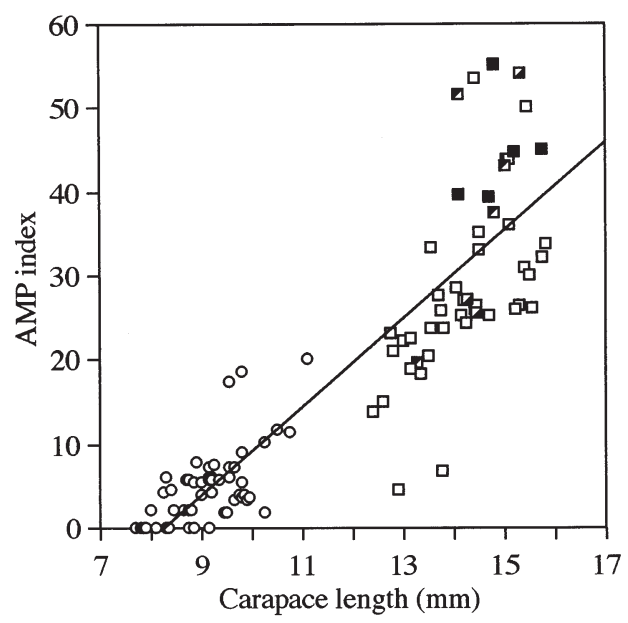

Fig. 3. Pandalus latirostris. Ratio appendix masculina length to endopod length of second pleopod (AMP) as a function of carapace length of individuals in Expt 1. Regression equation: $y=5.264 x+43.532\left(\mathrm{n}=99, \mathrm{r}^{2}=0.777, \mathrm{p}<0001\right)$. $\mathbf{~ : ~ s p e r m ~}$ stage in fast growth block; $\mathbf{\square}$ : spermatoblast stage in fastgrowth block; $\mathbf{\square}$ : spermatocyte stage in the fast growth block; $\square$ : immature in fast-growth block; $\mathrm{O}$ : immature in lategrowth block 
gonads in the sperm stage had a CL $\geq 14 \mathrm{~mm}$. The AMPs of individuals with developing gonads (i.e., spermatocyte, spermatoblast and sperm stages) ranged widely from 19.4 to 55.0. However, in general,

Table 1. Pandalus latirostris. Nested ANOVA on effect of food, hatching date, and maternal size on carapace length

\begin{tabular}{|c|c|c|c|c|}
\hline Source of variation & $\mathrm{df}$ & MS & $F$-value & $\mathrm{p}$-value \\
\hline \multicolumn{5}{|l|}{7 July } \\
\hline Food (A) & 1 & 90.521 & 87.091 & 0.0001 \\
\hline Hatch date (B) & 1 & 107.105 & 103.047 & 0.0001 \\
\hline Maternal size (C) & 1 & 5.426 & 5.220 & 0.0315 \\
\hline $\mathrm{A} \times \mathrm{B}$ & 1 & 47.114 & 45.329 & 0.0001 \\
\hline $\mathrm{A} \times \mathrm{C}$ & 1 & 0.016 & 0.015 & 0.9025 \\
\hline $\mathrm{B} \times \mathrm{C}$ & 1 & 0.085 & 0.082 & 0.7774 \\
\hline $\mathrm{A} \times \mathrm{B} \times \mathrm{C}$ & 1 & 0.937 & 0.902 & 0.3518 \\
\hline Cage $(\mathrm{A} \times \mathrm{B} \times \mathrm{C})$ & 24 & 1.039 & 4.978 & 0.0001 \\
\hline Error & 822 & 0.209 & & \\
\hline \multicolumn{5}{|l|}{3 August } \\
\hline Food (A) & 1 & 424.423 & 143.033 & 0.0001 \\
\hline Hatch date (B) & 1 & 160.283 & 54.016 & 0.0001 \\
\hline Maternal size (C) & 1 & 2.628 & 0.886 & 0.3560 \\
\hline$A \times B$ & 1 & 52.098 & 17.557 & 0.0003 \\
\hline $\mathrm{A} \times \mathrm{C}$ & 1 & 5.710 & 1.924 & 0.1781 \\
\hline $\mathrm{B} \times \mathrm{C}$ & 1 & 3.168 & 1.068 & 0.3118 \\
\hline $\mathrm{A} \times \mathrm{B} \times \mathrm{C}$ & 1 & 0.837 & 0.282 & 0.6003 \\
\hline Cage $(\mathrm{A} \times \mathrm{B} \times \mathrm{C})$ & 24 & 2.967 & 4.788 & 0.0001 \\
\hline Error & 648 & 0.620 & & \\
\hline \multicolumn{5}{|l|}{10 September } \\
\hline Food (A) & 1 & 572.880 & 137.698 & 0.0010 \\
\hline Hatch date (B) & 1 & 135.285 & 32.517 & 0.0010 \\
\hline Maternal size (C) & 1 & 3.764 & 0.905 & 0.3510 \\
\hline $\mathrm{A} \times \mathrm{B}$ & 1 & 27.474 & 6.604 & 0.0168 \\
\hline $\mathrm{A} \times \mathrm{C}$ & 1 & 0.482 & 0.116 & 0.7365 \\
\hline $\mathrm{B} \times \mathrm{C}$ & 1 & 0.170 & 0.041 & 0.8417 \\
\hline $\mathrm{A} \times \mathrm{B} \times \mathrm{C}$ & 1 & 3.955 & 0.951 & 0.3393 \\
\hline Cage $(\mathrm{A} \times \mathrm{B} \times \mathrm{C})$ & 24 & 4.160 & 2.414 & 0.0003 \\
\hline Error & 407 & 1.723 & & \\
\hline
\end{tabular}

higher AMPs were recorded for individuals in advanced gonadal stages, and the gonadal development of 9 of the 13 individuals that had AMPs > 37.5 was beyond the immature stage. All EMMs had AMPs > 39.4 .

Expt 2

Food amount and hatching date significantly affected the growth at 3 measurement times (Table 1). The difference in CLs due to difference in amounts of food gradually increased with time, and the difference due to difference in hatching dates was maintained until September (Fig. 4a,b). Moreover, interactions between both factors were observed on 3 measurement occasions (Table 1). The body sizes of newly hatched larvae were clearly related to maternal size, namely, larger females spawned larger larvae ( $\mathrm{n}=23$, $r^{2}=0.837, p<0.0001$; Fig. 5). Using a regression equation, the difference in CLs between 2 maternal size groups was estimated to be $\sim 0.2 \mathrm{~mm}$ (Fig. 5). Although a significant difference in CLs due to difference in maternal sizes was observed in July, the difference was not maintained until August (Table 1, Fig. 4c). Interactions among cages existed for 3 measurement times (Table 1).

\section{Field observations}

\section{Changes in water temperature in Saroma Lagoon}

Fig. 6 shows the monthly changes in mean water temperature during the growth season of Pandalus latirostris. Water temperatures in 1996 and 1997 were much colder than in the previous $9 \mathrm{yr}$.
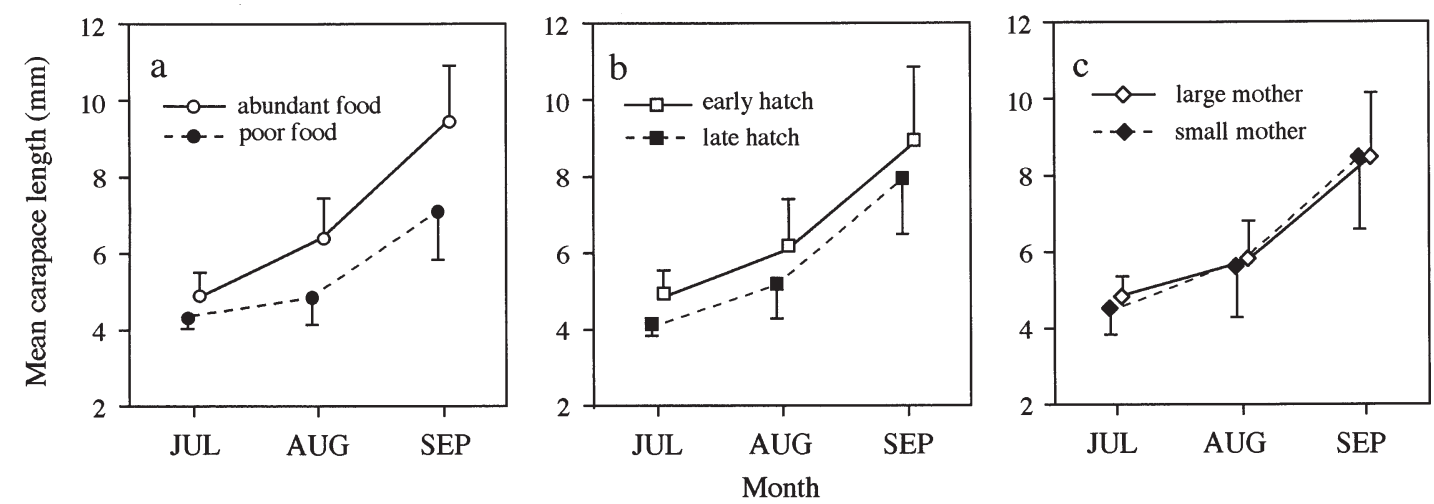

Fig. 4. Pandalus latirostris. Changes in mean carapace length in Expt 2 as a function of (a) food amount, (b) hatching date, and (c) maternal size. Vertical bars indicate standard deviations 


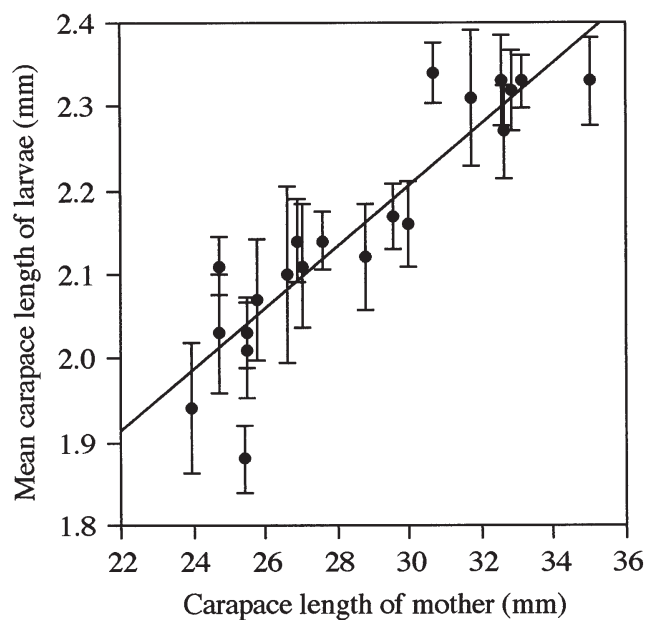

Fig. 5. Pandalus latirostris. Relationship between maternal size and larvae size. Regression equation: $y=0.037 x+1.106$ $\left(\mathrm{n}=23, \mathrm{r}^{2}=0.837, \mathrm{p}<0.0001\right)$. Vertical bars indicate standard deviations

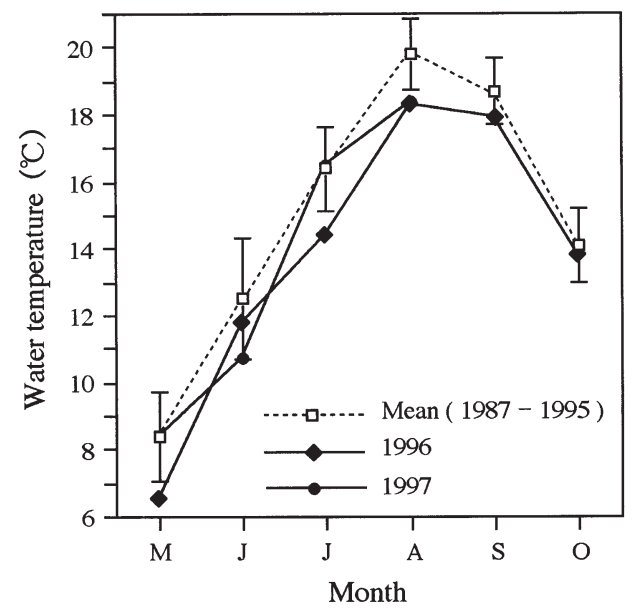

Fig. 6. Monthly change in mean water temperature in Saroma Lagoon. Vertical bars indicate standard deviation

Hatching season

Fig. 7 shows the temporal changes in the number of newly hatched larvae at Stn 3 in 1997. Hatched larvae were firstly caught on 21 May; the number increased rapidly to a peak on 31 May, and then decreased gradually. Because no newly hatched larvae were caught after 25 June, the hatching season of Pandulas latirostris at Stn 3 was estimated to last about 1 mo.

\section{Breeding season}

Fig. 8 shows the CL distribution of the Age-0 group at each station. Although there was no difference in

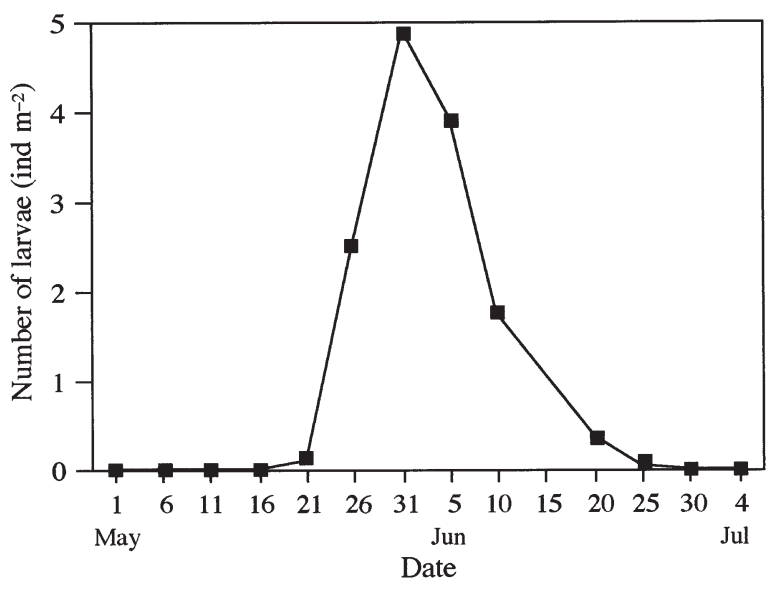

Fig. 7. Pandalus latirostris. Temporal changes in number of newly hatched larvae (5 d intervals) at Stn 3 in 1997

mean CL between stations in 1996 (ANOVA, $F=0.41$, $\mathrm{p}=0.66$ ), the mean $\mathrm{CL}$ at $\operatorname{Stn} 3$ was significantly smaller than at the other 2 stations in 1997 (ANOVA, $F=21.76, \mathrm{p}<0.001$, Fisher's PLSD Stns 1 and 3, Stns 2 and 3: $p<0.001$ ). Fig. 9 shows the percentage occurrence of EMMs in September at each station. Although there was no difference in the occurrence of EMMs among stations in 1996 ( $G$-test, $G=3.06$, p > 0.05), the percentage occurrence of EMMs at Stn 1 was significantly higher than at the other 2 stations in 1997 ( $G$-test, $G=10.67, \mathrm{p}<0.005)$. All EMMs had a developed vas deferens.

Neither the CL distributions within Saroma Lagoon (the sum of CLs at the 3 sampling stations) in September nor the percentages of occurrence of EMM differed significantly between years (CL distribution: ANOVA, $F=0.38, \mathrm{p}=0.54$; percentage occurrence of EMM: $G$-test, $G=1.14, \mathrm{p}>0.05)$.

\section{DISCUSSION}

Expt 1 clarified some questions concerning EMM Pandulas latirostris. This experiment dismissed any doubt that EMMs were extremely small, slow-growing normal males (Age-1), and showed that EMMs display rapid growth until the breeding season at Age-0. EMMs began producing sperm at $14 \mathrm{~mm}$ CL. Although the AMP index value of 50 has been used as a provisional criterion for identifying EMMs in past studies (Aoto 1952, Mizushima 1981a, Mizushima \& Omi 1982), these studies did not show a clear relationship between the AMP index and degree of maturation. In Expt 1, almost all individuals with developing gonads had AMP indices above 37.5. We confirmed that EMMs in the field were functional males. There- 

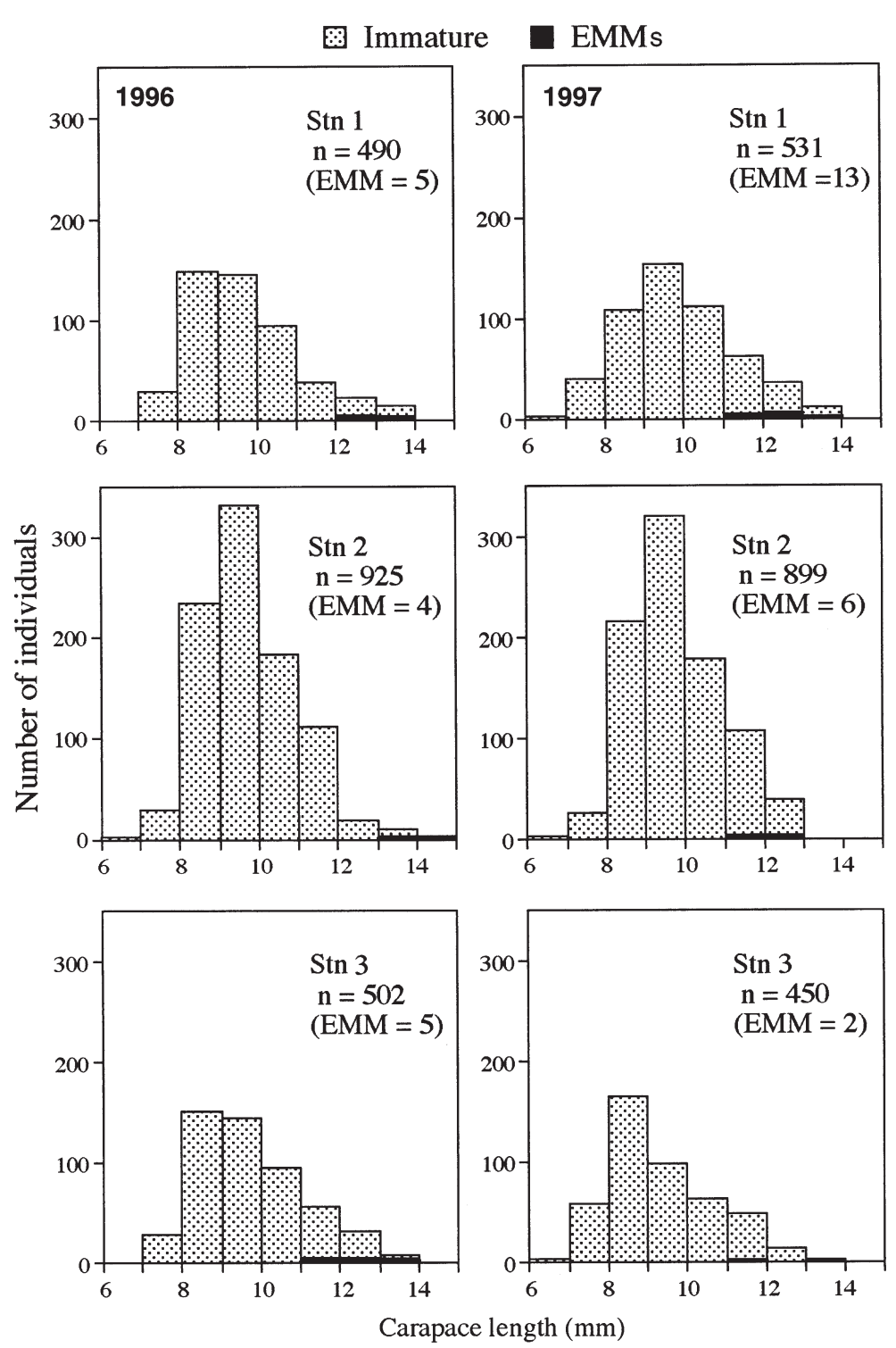

Fig. 8. Pandalus latirostris. Length-frequency distributions of Age-0 shrimp sampled at the 3 stations in Saroma Lagoon in September 1996 and 1997. EMMs: early maturing males

fore, the traditional definition of EMM based on AMP may be useful, although it was not sensitive, since 1 immature individual in Expt 1 had an AMP index above 50 .

We have to consider the effect of water temperature during the rearing period before Expt 1, because the rearing temperature was higher than the average temperature in June over the preceeding 9 yr in Saroma Lagoon. Omi \& Mizushima (1972) showed that early larval stages have a wide optimal temperature range for growth: from 10 to $16^{\circ} \mathrm{C}$ at the first stage $(4.5 \mathrm{~d}$ after hatching) and from 14 to $18^{\circ} \mathrm{C}$ at the second stage $(9 \mathrm{~d}$ after hatching). Because water temperatures $\left(\sim 18^{\circ} \mathrm{C}\right)$ during the preliminary rearing and the optimal temperature for growth were similar, we assume that the higher temperature during the preliminary rearing did not greatly affect larval growth during this period.

Expt 2 showed that the amount of food given caused the largest difference in CL. Unlike the adults, juvenile penaeid prawns feed continuously day and night (Reymond \& Lagardere 1990, Heales et al. 1996). In Pandulas latirostris, abundant food may be needed for early growth of juveniles because the molting interval of Age0 shrimp is much shorter than that of adults (Kurata 1955). Food quality is also an important factor influencing the growth of shrimps (Venkataramiah et al. 1975, Ouellet et al. 1995, Petit et al. 1997), and the fact that this species preys on many species (Mizushima 1981b) may reflect the requirement for high-quality food.

Difference in hatching dates may influence body development and, as a result, cause variations in life history (Schultz 1993, Yamamoto et al. 1997). In Pandalus latirostris, the hatching dates vary locally, even within the same bay (Mizushima \& Kakuda 1980, Mizushima et al. 1983). The present study showed that the hatching period at 1 location lasted for $\sim 1 \mathrm{mo}$. The results of Expt 2 suggested that a difference in hatching dates of $>2$ wk caused a large difference in body size, which persisted for $\sim 3$ mo later (i.e., until the breeding season). If the water temperature in the field notably increases with time during the hatching season, early- and latehatching individuals will undergo growth in different water temperatures, which will result in different molt intervals. Molt intervals of larvae of pandalid shrimps, for instance, decrease with

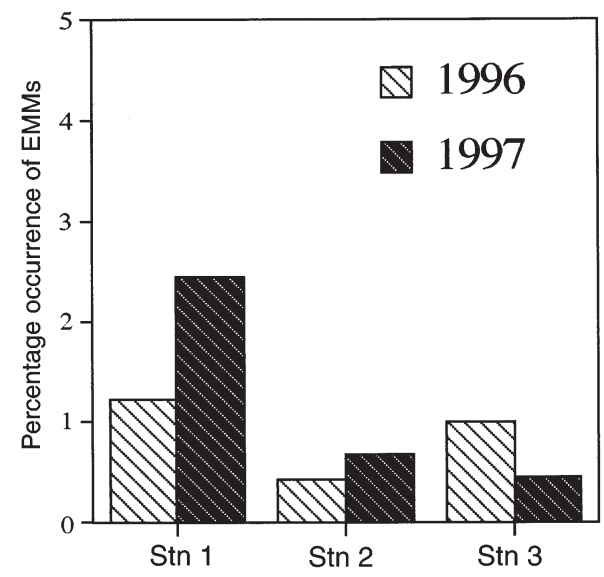

Fig. 9. Pandalus latirostris. Percentage occurrence of EMMs at the 3 sampling stations in September 1996 and 1997 
increasing temperature (Rothlisberg 1979, Schultze \& Anger 1997). However, in Expt 2, there was no difference in water temperatures between the 2 hatching groups. In the last $11 \mathrm{yr}$, data records (Saroma-ko Fisheries Cooperative Association of Aquaculture 1997) show no remarkable difference in water temperature in Saromako Lagoon between the hatching period of the early-hatching group (25 to 29 May: $9.6 \pm 0.4^{\circ} \mathrm{C}$ [SD]) and that of the late-hatching group ( 7 to 13 June: $\left.11.6 \pm 0.3^{\circ} \mathrm{C}[\mathrm{SD}]\right)$. Thus, molt intervals at an early larval stage may be similar for the first half and for the second half of the hatching season. Size difference arising from differences in hatching dates, therefore, may be maintained up to the breeding season, as confirmed by the results in Expt 2.

Maternal body size often influences egg size and/or offspring size (Parker \& Begon 1986, Glazier 1992), and large offspring grow faster than small offspring (reviewed by Roff 1992). Although the size of newly hatched larvae of Pandalus latirostris was affected by maternal body size, the size difference of larvae between the 2 maternal size groups in Expt 2 decreased with time. This suggests that maternal effect does not affect sequential growth of juveniles until the breeding season. However, large offspring generally exhibit higher survival than small offspring when food conditions are unfavorable (Mashiko 1985, Marsh 1986, Tessier \& Consolatti 1989), and may be better at acquiring food resources (Knutsen \& Tilseth 1985, Berejikian et al. 1996, Chaparro et al. 1999).

Feeding activity generally increases with increasing water temperature (Omi \& Mizushima 1972). Moreover, the hatching date also depends on an increase in water temperature (Mizushima \& Kakuda 1980, Mizushima et al. 1983). Locations where EMMs occur frequently are close to locations where early hatching occurs in Akkeshi Lagoon, eastern Hokkaido (Mizushima et al. 1983), but not in Notsuke Bay, eastern Hokkaido (Mizushima \& Kakuda 1980, Mizushima 1981a). Therefore, it is not certain whether the difference in body size caused by differing hatching dates persists until the breeding season. In our experiment, the growth of juvenile Pandalus latirostris was affected more by environmental conditions after hatching than by differences in hatching date. The age/size at sexchange in some pandalid shrimp is chiefly governed by genetic factors (Bergström 1992, 1997, Marliave et al. 1993). Based on our results from Expt 1, which showed that variation of AMP among individuals increased with increasing body size, genetic factors may affect the occurrence of EMMs. However, all individuals $<14 \mathrm{~mm} \mathrm{CL}$ in Expt 1 were immature, regardless of whether their siblings matured, so a genetic effect may be much smaller than the effect of food supply. We conclude that the amount of food is the most important factor affecting the growth and maturity of $P$. latirostris, and that it is strongly affected by abiotic factors, especially water temperature.

In Notsuke Bay, EMM frequencies are reported to vary from $0 \%$ to almost $50 \%$ (Mizushima 1981a, 1984). Such fluctuations have also been observed earlier in Saroma Lagoon (Mizushima unpubl. data). However, our field observations showed that the frequency ranged from 0 to $5 \%$. The only significant difference between locations occurred in 1997. The reason for this may be that our sample size may have been too small for comparisons. The yearly occurrence of EMMs did not differ significantly. In 1996/1997, we observed very few individuals larger than the 'critical' male maturation size (>14 mm CL estimated from the results of Expt 1). Omi \& Mizushima (1972) showed that the effect of water temperature on growth tends to be stronger with increasing juvenile stages. Because the water temperature in Saroma Lagoon in 1996/1997 was much colder than in the preceeding $9 \mathrm{yr}$, the low proportion of EMMs in our observations may have been caused by slow growth.

The sex-change of pandalid shrimps has been studied in deep-sea dwelling species, and variation in the occurrence of EMFs between localities have been discussed on latitudinal scales. For example, Butler (1964) and Charnov (1979) suggested that populations at lower latitudes have a higher proportion of EMFs because those individuals grow more rapidly (Rasmussen 1953). There are few conclusive reports showing which factors govern growth in pandalid shrimps, and the effect of water-temperature fluctuations in any one area is not clear (Shumway et al. 1985, Apollonio et al. 1986, Parsons et al. 1989, Bergström 1992). In shallow water, water temperature and/or the availability of food is much more variable among localities than in the deep sea. Therefore, the occurrence of EMMs in this species may fluctuate at small scales (e.g., within the same bay).

Early studies on the cause of annual fluctuations in the proportion of EMFs within any one water area have focused on correlations with age/size structure in a population each year: a reduction in the number of old females has been suggested to increase the proportion of EMFs (Charnov et al. 1978, Charnov \& Anderson 1989). Moreover, Bergström $(1992,1997)$ and Marliave et al. (1993) have suggested that the varying frequencies of genotypes programming for sex-change at different ages/sizes in populations may affect the occurrence of EMFs in pandalid shrimps. Although the possible relationship between EMMs and EMFs still remains undescribed, juveniles that become EMFs need to grow more rapidly than other individuals of the same age group because EMFs have to pass through a size range in which they are not large enough to pro- 
duce eggs. Therefore, the occurrence of EMFs and EMMs may be closely related to growth rate. We propose that the fluctuation in the proportion of EMFs in pandalid shrimps may be also caused by variations in growth that occur before males mature.

Acknowledgements. We are grateful to S. Sakazaki, Y. Hamade and K. Chida, Abashiri Marine Science Center, for providing the facilities for our laboratory experiment. H. Fujiwara, Tokoro Fishermen's Cooperative Association, and J. Ogura, Yubetsu Fishermen's Cooperative Association, are acknowledged for their close cooperation in the field observation. We express our appreciation to Y. Fujiyoshi, Saroma-ko Fisheries Cooperative Association of Aquaculture, for his help in carrying out this study. We also thank B. I. Bergström, J. R. Bower and 2 anonymous referees for constructive comments on the manuscript. Special thanks are due to S. Nakao and other members of the Laboratory of Benthology, Faculty of Fisheries, Hokkaido University, for their valuable comments. This work was financially supported by the Research Institute of Marine Invertebrates.

\section{LITERATURE CITED}

Aoto T (1952) Sexual phases in the prawn, Pandalus kessleri Czerniavski, with special reference to the reversal of sex. J Fac Sci Hokkaido Univ (Ser 6: Zool) 11:1-21

Apollonio S, Stevenson DK, Dunton EE (1986) Effects of temperature on the biology of the northern shrimp Pandalus borealis, in the Gulf of Marine. NOAA Natl Mar Fish Serv Tech Rep, US Dep Comm 42:1-22

Berejikian BA, Mathews SB, Quinn TP (1996) Effect of hatchery and wild ancestry and rearing environments on the development of agonistic behavior in steelhead trout (Oncorhynchus mykiss) fry. Can J Fish Aquat Sci 53: 2004-2014

Bergström BI (1992) Growth, growth modeling and age determination of Pandalus borealis (Kroyer). Mar Ecol Prog Ser 82:167-183

Bergström BI (1997) Do protandric pandalid shrimp have environmental sex determination? Mar Biol 128:397-407

Butler TH (1964) Growth, reproduction, and distribution of pandalid shrimp in British Columbia. J Fish Res Board Can 21:1403-1452

Chaparro OR, Oyarzun RF, Vergara AM, Thompson RJ (1999) Energy investment in nurse eggs and egg capsules in Crepidula diatata Lamarck (Gastropoda, Calyptraeidae) and its influence on the hatching size of the juvenile. J Exp Mar Biol Ecol 232:261-274

Charnov EL (1979) Natural selection and sex change in pandalid shrimp: test of a life-history theory. Am Nat 113: 715-734

Charnov EL (1982) The theory of sex allocation. Princeton University Press, Princeton, NJ

Charnov EL, Anderson PJ (1989) Sex change and population fluctuation in pandalid shrimp. Am Nat 134:824-827

Charnov EL, Gotshall DW, Robinson JK (1978) Sex ratio: adaptive response to population fluctuations in pandalid shrimp. Science 200:204-206

Ghiselin MT (1969) The evolution of hermaphroditism among animals. Q Rev Biol 44:189-208

Glazier DS (1992) Effects of food, genotype, and maternal size and age on investment in Daphnia magna. Ecology 73: 910-926
Haynes EB, Wigley RL (1969) Biology of northern shrimp, Pandalus borealis, in Gulf of Marine. Trans Am Fish Soc 98:60-76

Heales DS, Vance DJ, Loneragan NR (1996) Field observations of molt cycle, behavior, and diet of small juvenile tiger prawn Penaeus semisulcatus in Embley River, Australia. Mar Ecol Prog Ser 145:43-51

Holthuis LB (1995) Notes on Indo-West Pacific Crustacea Decapoda III to IX. Zoöl Meded, Leiden 69:139-151

Kashiwagi M (1974) Ecological studies on the 'Hokkai-Ebi', Pandalus kessleri, found in Yamada bay- II. On development and reversal of sex with growth. Bull Jpn Soc Sci Fish 40:985-992 (in Japanese with English summary)

Knutsen GM, Tilseth S (1985) Growth, development and feeding success of Atlantic cod larvae Gadus morhua related to egg size. Trans Am Fish Soc 114:507-511

Kubo I (1951) Bionomics of the prawn, Pandalus kessleri. J Tokyo Univ Fish 38:1-26

Kurata H (1955) The post-embryonic development of the prawn, Pandalus kessleri. Bull Hokkaido Reg Fish Res Lab 12:1-15

Marliave JB, Gergits WF, Aota S (1993) $F_{10}$ pandalid shrimp: sex determination; DNA and dopamine as indicators of domestication; and outcrossing for wild pigment pattern. Zoo Biol 12:435-451

Marsh E (1986) Effects of egg size on offspring fitness and maternal fecundity in orangethroat darter, Etheostoma spectabile (Pisces: Percidae). Copeia 1986:18-30

Mashiko K (1985) Comparison of survival and development between large and small neonates of a freshwater prawn under starvation condition. Zool Sci 2:397-403

Mizushima T (1981a) Occurrence and distribution of male in 0-age group of shrimp, Pandalus kessleri in Notsuke Bay, Hokkaido. Month J Fish Exp Stn Hokkaido 38:121-131 (in Japanese)

Mizushima T (1981b) Ecology and catch of the prawn, Pandalus kessleri in Zostera beds in Notsuke Bay, Hokkaido, Japan. In: Japanese Society of Scientific Fisheries (ed) Seaweed beds. Kouseisha Kouseikaku, Tokyo, p 57-74 (in Japanese)

Mizushima T (1984) Distribution of Pandalus kessleri Czerniavsky in spawning season in Notsuke Bay. Month J Fish Exp Stn Hokkaido 41:69-81 (in Japanese)

Mizushima T, Kakuda T (1980) On the distribution of larvae of the prawn, Pandalus kessleri, in Notsuke Bay, Hokkaido. Month J Fish Exp Stn Hokkaido 37:87-101 (in Japanese)

Mizushima T, Omi H (1982) Growth and sexual phases of the shrimp, Pandalus kessleri Czerniavsky, in the Notsuke Bay, Hokkaido, with special reference to the two types of growth. Sci Rep Hokkaido Fish Exp Stn 24:15-27 (in Japanese with English summary)

Mizushima T, Miyamoto M, Mabuchi M(1983) Growth and distribution of Pandalus kessleri Czerniavsky in Akkeshi. Month J Fish Exp Stn Hokkaido 40:111-125 (in Japanese)

Omi H, Mizushima T (1972) Effect of water temperature on growth of early stage of Pandalus kessleri Czerniavsky. Month J Fish Exp Stn Hokkaido 29:2-11 (in Japanese)

Ouellet P, Taggart CT, Frank KT (1995) Early growth, lipid composition, and survival expectations of shrimp Pandalus borealis larvae in the northern Gulf of St. Lawrence. Mar Ecol Prog Ser 126:163-175

Parker GA, Begon M (1986) Optimal egg size and clutch size: effects of environment and maternal phenotype. Am Nat 128:573-592

Parsons DG, Mercer VL, Veitch PJ (1989) Comparison of the 
growth of north shrimp (Pandalus borealis) from four regions of the northwest Atlantic. J Northw Atl Fish Sci 9:123-131

Partridge L, Harvey PH (1985) Costs of reproduction. Nature 316:20

Petit H, Nègre-Sadargues G, Castillo R, Trilles J (1997) The effects of dietary astaxanthin on growth and moulting cycle of postlarval stages of prawn, Penaeus japonicus (Crustacea, Decapoda). Comp Biochem Physiol 117A: $539-544$

Rasmussen B (1953) On the geographical variation in growth and sexual development of the deep sea prawn (Pandalus borealis Kr.). Rep Norw Fish Mar Invest 10:1-160

Reymond H, Lagardère JE (1990) Feeding rhythms and food of Penaeus japonicus Bate (Crustacea, Penaeidae) in salt marsh pond: role of halophilic entomofauna. Aquaculture 84:125-143

Roff DA (1992) The evolution of life histories; theory and analysis. Chapman \& Hall, New York

Rothlisberg PC (1979) Combined effects of temperature and salinity on the survival and growth of the larvae of Pandalus jordani (Decapoda: Pandalidae). Mar Biol 54: 125-134

Saroma-ko Fisheries Cooperative Association of Aquaculture (1997) Observation for water quality in Lagoon Saroma. In: Annual Business Report of Saroma-ko Fishermen's Association of Aquaculuture for 1997. Saroma-ko Fisheries Cooperative Association of Aquaculture, Hokkaido, p 174-192 (in Japanese)

Schultz ET (1993) The effect of birth date on fitness of female

Editorial responsibility: Otto Kinne (Editor),

Oldendorf/Luhe, Germany dwarf perch, Micrometrus minimus (Perciformes: Embiotocidae). Evolution 42:520-539

Schultze K, Anger K (1997) Larval growth patterns in the aesop shrimp Pandalus montagui. J Crustac Biol 17: 472-479

Shumway SE, Perkins HC, Shick DF, Stickney AP (1985) Synopsis of biological data of the pink shrimp Pandalus borealis (Kroyer, 1838). NOAA Natl Mar Fish Serv Tech Rep, US Dep Comm 30:1-57

Sitonikov AV, Kartavtsev YF, Nikiforov SM (1997) Estimation of the effective size of a grass shrimp (Pandalus kessleri) population by a temporal method and direct census of breeders during breeding season. Russian J Genetics 30: 1158-1164

Tessiser AJ, Consolatti NL (1989) Variation in offspring size in Daphnia and consequences for individual fitness. Oikos 56:269-276

Tsutsumi H (1990) Measurement of body length, drawing figure of length frequency distributions and generation analysis. In: Programs of resource analysis by using personal computer, edited by National Research Institute of Fishery Science, Tokyo, p 54-68 (in Japanese)

Venkataramiah A, Lakshmi GJ, Gunter G (1975) Effect of protein level and vegetable sequential hermaphroditism in animals. Am Nat 109:61-82

Warner RR (1975) The adaptive significance of sequential hermaphroditism in animals. Am Nat 109:61-82

Yamamoto S, Shinomi H, Goto A (1997) The effect of birth date on growth of juvenile white-spotted charr Salvelinus leucomaenis. Fish Sci 63:931-933

Submitted: July 6, 1999; Accepted: May 5, 2000

Proofs received from author(s): August 24, 2000 